\title{
Back to basics: assessing military involvement in politics in contemporary Brazil
}

\author{
Marina Vitelli
}

\begin{abstract}
As Brazil showed signs of progress in civil-military relations in the late nineties and early 2000s, research moved from civilian control to defense policy topics, resulting in the neglect of less obvious forms of military involvement in politics, many of which pre-date the presidency of Jair Bolsonaro. After critically reviewing existing frameworks for assessing progress in civilian control we propose returning to the field's primary concern with military intervention in politics by using three indicators - military presence in government; public commentary by military officers; and episodes of military contestation - and their implications regarding the armed forces, politicians, and society. Next, we examine these three indicators in the context of the presidencies of Dilma Rousseff and Michel Temer. We conclude that interactions between "soldiers, politicians, and civilians" in recent episodes of military involvement in politics reveal the full extent of the frailty of civil-military relations in Brazil.
\end{abstract}


Following the election of President Jair Bolsonaro in October 2018, Brazil saw the return of military officers in daily news headlines. Not because the country was at war, or due to a sudden media interest in defense issues, but because the president had filled cabinet positions with both retired and active-duty officers. Military presence in government rose exponentially - and seemingly unexpectedly - in a country that had left behind military rule three decades earlier. In 2020, Brazilians experienced another déjà vu: jurists, political analysts, and retired officers, including the president, were suddenly debating whether or not the military was allowed to intervene in conflicts between branches of power, such as those arising between the executive and the judiciary in the early months of the COVID-19 pandemic. Both the media and the academic sphere found themselves suddenly debating a subject they thought had been left in the past.

Indeed, not long before 2018, Brazilian academic debates on issues of defense and the military was thriving. Over the course of the preceding decade, a self-confident middle power and regional leader encouraged the diversification of studies on defense policy and the armed forces, with increasing civilian involvement in the discussion. After the transition to democracy, scholars had focused almost exclusively on the "military question": how would the new democracy cope with a military that retained such high levels of autonomy? But the positive evolution of civilmilitary relations challenged scholars' skepticism. As the military no longer seemed a threat to democracy, the area of defense studies extended to issues beyond the theme of civilian control, such as peace operations, regional defense cooperation, and defense technology projects. Despite the persistence throughout the decades of experts that remained doubtful of actual progress in civilmilitary relations, there was widespread agreement that the armed forces' involvement in politics was a thing of the past.

In fact, a similar impression was implicit in the broader study of defense and the armed forces in Latin America. As the military began abstaining from influencing politics, governments faced another agenda of reforms: those needed to assert civilian control over defense policy. To be sure, both are relevant goals for a healthy democracy. However, while a democratic regime implies that no policy arena is barred from the decision of authorities with democratic legitimacy, affirming civilian authority on decisions such as the defense budget, strategic planning, or defense diplomacy are less problematic for democratic stability than making sure the armed forces do not exert their power on the political process itself, which seems to be the case in Brazil.

Military presence in Bolsonaro's government might be the most striking feature of their recent involvement in politics. However, it is important to note that signs of increased military power predate the election of a presidential ticket featuring two retired officers. More precisely, Dilma Rousseff's last years in office already featured subtle, yet unsettling tensions with the military while her successor, Michel Temer, reversed a policy of non-inclusion of military officers in cabinet.

In a way those signs went unnoticed because experts - quite understandably - considered that progress on neutralizing the military as a political actor was considerable enough to justify a change in focus. This shift in priorities was reflected in both research topics about Brazil and its armed forces and in conceptual frameworks advanced in the field of Latin American civil-military relations. In other words, while the literature made outstanding progress in building analytical tools to assess the reduction of military prerogatives over Brazilian defense policy, it overlooked variables 
and dimensions related to the armed forces' influence in politics in general, particularly those which are closely related to the principle goal of the country's democratization: the political neutralization of the military. In order to bring back those factors front and center we suggest a refocus on military involvement in politics by observing three indicators of increased political influence by the armed forces: a) military presence in government; b) public commentary about political events by military officers; and c) episodes of military contestation. Drawing on Pion-Berlin and Martinez' three-tiered approach, this article argues that there are signs of a problematic adherence to the norm of nonintervention in politics by the military across three main groups: the armed forces, politicians, and society. This three-tiered framework will then be applied to show the ways in which the Brazilian military has increased its intervention in politics during the governments of Rousseff and Temer, while also discussing politicians' and society's reactions. The article concludes that the frailty of civil-military relations in Brazil is a multifaceted and pervasive social phenomenon and suggests questions for further research.

\section{The study of Brazilian civil-military relations: from democracy to defense and back}

After the demise of military regimes in the 1980s, research on Latin American's armed forces followed a rather logical path, one associated with transitions to democracy. In general terms, when transitioning from military to civilian rule, not only do democratic authorities need the armed forces to step down from government, but civilians also need to make sure the military will no longer interfere in politics in any way. In other words, in democratic regimes the armed forces are expected to be politically neutral: they allow neither partisanship inside the barracks, nor institutionally articulated deliberation about domestic politics which could lead the armed forces to formulate a political agenda of their own (Martínez, 2013). While the depth, features, and pace of those reforms varied from nation to nation, the ultimate goals were the same for every country which sought to become a representative democracy. First, it was necessary to eliminate the armed forces' ability to interfere in politics. Second, civilians had to exert control on defense policy (Fitch, 1998, pp. 36-60).

Because of the characteristics of its military regime and, consequently, of its transactional transition, Brazil was always considered a hard case for civilian control. A relatively successful military regime managed to negotiate the terms of a long, gradual transition that allowed the armed forces to maintain moderate to high levels of prerogatives (Dreifuss et al., 1987; Stepan, 1988). In contrast, other scholars noticed that democratic political dynamics succeeded in eroding military power, reducing military autonomy in certain areas (Hunter, 1997). The result was not exactly an ideal democratic model, though the balance was certainly substantially more democratic than what scholars had predicted (Bruneau \& Tollefson, 2014).

In general terms, it is fair to say that by the beginning of the XXI century the Brazilian military - and most other Latin American armed forces - was less visibly involved in politics, leading to the impression that the first stage of a democratic regime of civil-military relations had been completed. This assessment of progress opened the academic field to research about issues more closely related to defense policy, such as defense ministries, the interplay between defense and foreign policy, 
effectiveness, and efficiency, among other things. While some of the literature still dealt with civilian control concerns, it is worth noting that they presupposed the absence of a military threat to democratic stability.

To be fair, Brazil's progress was usually assessed with a mix of praise and skepticism. While recognizing that the creation of the Ministry of Defense was a significant step forward, many scholars remained critical of the predominance of retired officers as ministry officials and its lack of civilian permanent personnel (Fuccille, 2006; Marques, 2004; Saint-Pierre \& Winand, 2008). Similarly, experts were dissatisfied with the limited influence that civilians had on the drafting of strategic documents published during Lula da Silva's and Dilma Rousseff's administrations (Saint-Pierre \& Winand, 2010). In contrast, Bruneau and Tollefson (2014) presented a positive evaluation of the reduction in military prerogatives. But, while analysts often argued that the country had not yet achieved the ideal level of civil-military relations, in general terms, they agreed that Brazilian armed forces had renounced intervention in politics. Brazil had armed forces that resisted civilian leadership over defense policy and protected their autonomy over the military's core institutional interests, such as education and promotions, but were not deliberately seeking to be a political actor again. At least until 2015.

Studies on civil-military relations in Brazil were not the only ones to assume that military involvement in politics was no longer a problem. In fact, as more patent signs of political interference by the armed forces dramatically decreased in the beginning of the $21^{\text {st }}$ century, the field's main conceptual developments were also turning away from concerns with the military and politics. In an attempt to reconnect many of the civil-military relations' sub-issues that arose over the past three decades, Pion-Berlin and Martínez (2017) proposed a holistic approach to evaluate progress in military transformation. Insofar as military reform is assessed in direct relation with democratization, their approach has the merit of returning to the field's traditional concern with democracy. Its holistic quality is also in the fact that, instead of only focusing on the armed forces, the authors include politicians and society through six dimensions, each of them opening a window into civil-military relations: military power, legal frameworks, defense institutions, knowledge, convergence, and effectiveness (2017, p. 14). Progress in each dimension is then related to three phases of the democratization process: transitional, consolidating, and consolidated. When applied to Brazil, the framework showed the country's many pending challenges in achieving democratic civilian control of their armed forces. Compared to Argentina, Chile, and Uruguay, Brazil ranked highest in civil-military relations during the transition phase (2017, p. 343).

Pion-Berlin and Martínez's framework is an exceptional contribution to systematizing indicators of progress in civil-military relations with a clear concern for democracy. However, the framework seems better suited to assessing progress (and, less so, regression) in democratization's second goal - civilian involvement in formulation, implementation, and oversight of defense policy - than for evaluating improvement regarding democratization's first goal of eliminating the military's role in politics. The only component directly related to apolitical, non-deliberative armed forces is the "Policymakers and Policy" component of the Military Power dimension, which includes three subcomponents: leadership selection, policy selection, and public defense enterprises, the first of which can account for an increase in military officers occupying otherwise typically civilian positions, such as ministries other than defense. Nevertheless, the framework does not include other 
elements necessary to account for the deterioration in conditions that guarantee political neutrality of the armed forces and their non-interference in domestic politics, almost as if the authors' framework included the consolidation of that first goal as a prerequisite. To be able to identify lack of progress or even regression regarding military involvement in politics and, in this way, help making sense of signs of military political activism in contemporary Brazil, the Military Power dimension would do well to incorporate Military Interference in Politics as a fourth component, with three indicators: a) military presence in government; b) public commentary on political events by military officers; and c) episodes of military contestation.

In order to preserve the political neutrality of the armed forces, democracies usually prohibit their active-duty officers from being employed in government positions, however, there is often more variance regarding the appointment of retired officers. Admittedly, hiring retired officers is not necessarily a sign of increasing proximity between the military as an institution and politics. In fact, Brazilian armed forces claim that the officers serving in Bolsonaro's cabinet are working for the government on a purely individual capacity. Moreover, no consensus has been reached regarding what proportion of government officials of military origin might indicate that the military as an institution is exerting significant political power. Instead of using the indicator of military presence in government in quantitative terms, we choose to highlight the trajectory of political activism of top-ranking military officers in Bolsonaro's government over the course of preceding governments, as well as the relationship between that activism and the political scene.

The other two indicators - military officers' public commentary on political events and episodes of military contestation - refer to Alfred Stepan's conflict dimension of democratic civilian control (1988). Military contestation and public commentary about political events are similar in that they feature officers uttering their views. However, they differ in two ways. First, episodes of military contestation express rejection of governments' actions, while public commentary is not necessarily critical of particular policies, nor is it necessarily aimed at specific authorities. Also, while the latter constitutes actions performed by officers as individuals, the former is a collective reaction, thus conveying an institutional view.

In theory, a military that is more assertive in its attempts to resist civilian control and that abandons political neutrality is likely to become involved in episodes of articulated opposition to civilians, both publicly and otherwise. In such instances, it is necessary to observe both actors: the armed forces contesting civilians, and civilians' reaction to conflict. As Stepan puts it, the ultimate test of military contestation is, on the one hand, whether civilians manage to stand their ground in the face of the armed forces' defiance, and on the other hand, whether military responses to civilians not backing down does not jeopardizes democracy (Stepan, 1988, p. 98). In contrast, low levels of conflict that result from civilians excessively accommodating military demands is a sign of continued military influence, not civilian control. Bearing this in mind and drawing on Pion-Berlin and Martínez's three-tiered framework, each of the indicators will be assessed considering the three actors involved: the military, politicians, and society.

The remainder of this article offers a description of episodes related to the three indicators during Dilma Rousseff and Michel Temer's presidencies. This section is based on incidents relating to the military's presence in government, public commentary, and military contestation included in 
the systematic account of news about Brazilian armed forces and defense issues published on a weekly basis by the Defense and International Security Study Group (GEDES) ${ }^{1}$. The chronological account is then followed by a discussion of the ways in which the incidents represent a risk for Brazilian democracy, considering their impact on the three tiers: the military, politicians, and civilians.

\section{The Brazilian military's return to politics}

\section{$\underline{\text { Rousseff: rising military contestation }}$}

Rousseff's administration (2011-2016) neither reduced nor increased military presence in cabinet positions, but her administration saw significantly higher levels of tension between the Executive and the armed forces when compared to previous presidents. Civilians' response to conflict, however, was the same as many previous instances of contestation: appeasement instead of reprimand. Also, as the institutional crisis that ended in her ousting began to form, top-rank military officers increased their involvement in public political debate.

During her first years in office, the president clashed with the military regarding the replacement of Nelson Jobim as minister of Defense for Celso Amorim in September 2011. Jobim had been Lula da Silva's defense minister since 2007 and Rousseff kept him in her cabinet when she took office, in January 2011. But as Jobim made a series of statements criticizing other government officials, the president decided to ask for his resignation and appointed the former chancellor in his place. The press reported the services' discontent by publishing off-the-record statements made by several officers who not only supported Jobim, but also strongly disapproved of his replacement on ideological and organizational grounds. They resented Amorim's alleged support for Hugo Chavez in Venezuela. Also, the military distrusted his diplomatic origins, which, according to them, made him an unsuitable leader for defense policy (GEDES, 2011a, 2011b). Regardless of the soundness of their arguments, it must be noted that the armed forces managed to have their dissatisfaction conveyed across national media, even though they refrained from articulating the contestation institutionally.

Another instance of contestation that made the headlines was the military's reaction to a presidential decree published in early September 2015 delegating decisions on military personnel issues to the defense minister (Monteiro, 2015a). A presidential prerogative by constitutional provision, it was military commanders who, in practice, decided which officers were transferred to reserve or retirement and, more importantly, which ones were promoted to senior rank, among other personnel decisions. In what appeared to be an attempt to strengthen the ministry's position relative

\footnotetext{
${ }^{1}$ The next section includes every instance of public commentary and military contestation that were found across all of GEDES's 182 weekly reports published between 2015 and 2018, all of which are available here https:/gedesunesp.org/observatorio-sul-americano-defesa-forcas-armadas/
} 
to the service branches, the decree gave the minister a series of prerogatives relating to military personnel. Despite the fact that it also authorized the minister to "subdelegate" the faculties to the service commanders, the decree caused great discontent among senior officers (GEDES, 2015). The military complained they had been neither consulted nor previously informed on the decision, and even criticized the timing of the government to reduce military prerogatives "in the midst of a political crisis affecting the president" (Godoy, 2015). While, once again, the armed forces abstained from articulating their discontent through formal institutional channels and instead took their distress to the press, civilian reactions to contestation was of complete accommodation: the defense minister asserted that the government had no actual intentions of reducing the commanders' powers in personnel decisions and, within days form the incident, signed an administrative resolution that edited the presidential decree, which in practice resulted in neutralizing the delegation (Monteiro, 2015a).

But the most crucial tension between Rousseff and the armed forces relates to Brazil's attempt to investigate human right violations committed during the dictatorship, almost three decades after its end. In fact, the initiative to create a Truth Commission was launched in December 2009, more precisely, as a feature of President Lula da Silva's third National Plan for Human Rights. At the time, the service commanders met with the defense minister to express their indignation regarding the initiative (Cantanhêde \& Iglesias, 2009). Instead of trying to convince the officers to accept the government's decision, or at least negotiate their acquiescence, the defense minister was more sympathetic to the commanders' concerns: some months later, during a public hearing in Congress, Jobim confided he had considered resigning if the government insisted on the proposal (Moraes, 2010).

Rousseff's administration managed to appoint the members of National Truth Commission in 2012. However, the military refused to collaborate with the investigations, even when the Commission lacked prosecution powers. Criticizing the government's decision to examine only crimes committed by the military - instead of including those on the count of guerrilla organizations - the three service branches systematically undermined investigations (GEDES 2014). In addition, when the final report was published, associations of retired officers - the Military Clubs - publicly condemned the document (Monteiro \& Tosta, 2014). More importantly, an active duty officer general Sergio W. Etchegoyen - at the time serving in the Army High Command - published a grievance note concerning the naming of his late father - also an army general - as one of the officers responsible for human rights violations (Monteiro, 2014). This act of insubordination went unpunished, even when military law is clear about banning public statements by active-duty members of the armed forces.

In January 2015, Rousseff started her second term in office already in crisis. She won the election on an extremely close margin, which led her competitor - Aécio Neves - to question the results in the courts. Also, she was still under heavy criticism and mounting social unrest due to an economic recession and corruption investigations on her party colleagues. As the institutional crisis deepened, including rumors on opposition's plans to impeach her, top-rank military officers, both retired and in active duty, began commenting publicly about the political turmoil. 
In October 2015, the Army Commander, General Eduardo Villas Bôas, gave a speech that was broadcasted to 2,000 temporary reserve officers. In his address to fellow officers the general expressed his concerns about the institutional crisis potentially developing into a "social crisis, which would affect the country's stability, thus becoming an issue pertaining to the armed forces" (Vizeu, 2015). Some weeks earlier, South Military Commander General Antonio Hamilton Mourão had made controversial statements to a military audience. On September 17th, three years before becoming Bolsonaro's Vice-President - while addressing reserve officers at a military facility, Mourão discussed political events and even encouraged "everyone who is autonomous, free and decent to awaken to the patriotic struggle to get the country out the political crisis" (Stochero, 2015).

These episodes in which top-rank military officers publicly stated their views on domestic politics were met with excessive caution by civilians. There is no record of General Villas Boas having been summoned by then-Minister of Defense, Aldo Rebelo. Analogously, Mourão was not properly sanctioned for his public comments on the ongoing institutional crisis. The situation was dealt with directly by the Army Chief, not the higher civilian authority, and the penalty was moderate: General Mourão was transferred to a bureaucratic position in Brasília, loosing command over troops, but still occupying a seat at the Military High Command. General Villas Bôas also talked publicly about the institutional crisis between the Executive and Congress, and despite always being very careful with his words to avoid explicit interference in politics, the mere fact of a military authority making unsolicited statements about a situation that had his Commander in Chief against the ropes is noteworthy of attention, particularly considering that the crisis ended in Rousseff's impeachment.

\section{Temer: generals speak up}

During the 32 months of Michel Temer's time as president, military presence in cabinet and in other government positions rose. Most notably, there was an escalation of public commenting by military officers.

As soon as he took office, Temer appointed General Etchegoyen as Chief of the Institutional Security Cabinet of the presidency (GSI), recreating a position that had been eliminated by Rousseff some months earlier. Later, in March 2018, the president discontinued Brazil's custom of appointing civilians as ministers of Defense, when he transferred defense minister Raul Jungmann - a civilian - to the newly created Ministry of Public Security and assigned General Joaquim Silva e Luna ${ }^{2}$ as Jungmann's replacement. Interestingly, Jungmann substituted another military officer - General Carlos Alberto dos Santos Cruz - who had served as secretary of Public Security since April 2017, when the division was still part of the Ministry of Justice. Army officers were also appointed in less influential though still politically sensitive positions, such as the National Indian Foundation (FUNAI), headed by General Franklimberg Ribeiro de Freitas.

\footnotetext{
${ }^{2}$ General Silva e Luna had been appointed as Secretary General of the Defence Ministry still during Dilma Rousseff's term. The position had been created rather recently as part of reforms aimed at increasing civilian control. In contrast, in October 2015, after Rousseff named Aldo Rebelo as the new Defence Minister, Silva e Luna replaced a civilian as Secretary General.
} 
While Temer's decision to appoint retired generals may have been a strategy to bolster his weak presidency marked by historically low approval ratings (Caram, 2017), other important political leaders with no such deficits of legitimacy also invited military officers as advisors. In October 2018, Minister of the Supreme Court José Antonio Dias Toffoli appointed a retired army general, Fernando Azevedo e Silva, as his advisor. The general was already working with Bolsonaro's campaign and would later be part of his cabinet. Another presidential candidate, Geraldo Alckmin, also hired military advice during the campaign when, in June 2018, General João Camilo Pires de Campos joined Alckmin's team to counsel on public security proposals (Vettorazzo, 2018).

Rousseff's ousting failed to end political turbulence in Brasilia and scandals during Temer's term did not go unnoticed by the generals. Both active and retired officers, some of whom later filled positions in Bolsonaro's administration, made public statements regarding such political events. In May 2017, the press reported leaked conversations between Temer and businessman Joesley Batista, in which the president seemed to endorse a monthly bribe to secure the silence of Eduardo Cunha, ousted president of the Chamber of Deputies, jailed on counts of corruption only months after he organized Rousseff's impeachment. Neither the Army Commander nor any other top-ranking officer made statements when the political crisis involving the president erupted, which some interpreted as an endorsement. However, a few months after the episode, General Mourão openly shared his frustration regarding the presidential scandal while giving a speech at a Masonic lodge. He asserted that "Either institutions solve the political problem, through the action of the Judiciary, removing from public life these elements involved in all illicit acts, or else we will have to impose that" (Valente, 2017). His second high profile political statement caused more concern than his criticism of Rousseff's government, probably because the choice of words resembled a warning of a coup. However, he once again did not receive the corresponding disciplinary action (Gregorio, 2017). While newspapers informed that the defense minister had asked the Army Commander to look into the matter (Gielow, 2017), General Villas Bôas considered that a formal reprimand could be counterproductive: given that Mourão's outlook on the political scenario was widespread among the military, punishing the general was likely to create a martyr and foster politization in the barracks (Gregorio, 2017).

This episode involved different indicators of deteriorated civilian control. It started with an active duty, high ranking officer publicly analyzing national politics in an explicit manner, obliquely criticizing his Commander in Chief, and making an ambiguous call to action to his colleagues. Even though the Minister of Defense reacted, he chose to delegate the matter to the Army Chief and did not question the general's decision to dismiss disciplinary action.

Interestingly, the more striking episode of a military officer making a public statement about domestic politics took place six months after that, featuring Villas Bôas himself. In April 2018, the Supreme Court was about to rule on former president Lula da Silva's appeal to have his twelve-year prison sentence postponed until his case was reconsidered by the high court, which would allow him to run for president in the October elections. Hours before Judge Rosa Weber announced her decisive vote on the matter, the Army Commander used his twitter account to make a bold statement: "I assure the Nation that the Brazilian Army believes that it shares the desire of all citizens 
to repudiate impunity and respect the Constitution, social peace and democracy, while remaining watchful of its institutional missions"3.

Some political leaders and members of civil society organizations expressed their concerns regarding what they interpreted as a veiled attempt to coerce a judicial decision (Vassallo, 2018). Others understood that there were no signs of Judge Weber changing her vote out of fear of a military coup. To be fair, Villas Boas' message may have neither determined the Supreme Court vote, nor decided Lula's fate as a candidate. But that obscures the fact of the utter abnormality of the Chief of the Army publicly articulating the view of the service about crucial political events, for which he received no disciplinary sanction by civilian authorities. Claims that the tweets were merely personal opinion are unwarranted not only because Villas Bôas was the highest Army authority, but also - as the general reviled in a recent book - because members of the Army High Command were involved in choosing the final wording of the message (Castro, 2021: 189).

In addition, in his defense of his public intervention, Villas Boas once again mentioned unrest among the rank and file: had he not communicated the army's opinion about the matter, he would have risked discipline in the barracks (Gielow, 2018). In other words, the tweet was not only a message from the High Command: it was also an indicator of a politicized army, from top to bottom.

\section{"Soldiers, politicians, and civilians" and military involvement in politics in contemporary Brazil}

These instances of either implied or explicit criticism of government actions by active-duty officers, public commentary on domestic politics that went unsanctioned - including a veiled veto on a supreme court decision -, and the appointment of previously politicized military officers, all point to an increase in military involvement in politics. Moreover, a careful look at the specifics of those episodes, as well as politicians' and society's attitudes towards them, give us a more sophisticated view of the extent to which current military involvement in Brazilian politics endangers democracy. Figure A summarizes our considerations.

\section{Military presence in government:}

The quantity and type of positions filled with military officers are clear indicators of the militarization of government, that is, to what extent civilians value the armed forces as a source of top-rank government officials. Elements such as overall percentage of uniformed men appointed to lead first and second level government positions, however, tell us more about militaristic views among civilians than about the extent to which the armed forces as an institution are interested in taking their own self-conceived political views to government. Bearing in mind that our focus is examining how the armed forces may reenter Brazilian politics as actors, thus endangering one of democracy's pillars, we choose to stress the link between that presence and current political

\footnotetext{
${ }^{3}$ Villas Bôas tweets can be accessed here:

https://twitter.com/gen_villasboas/status/981315180226318336?lang=pt
} 
processes in order to know whether the appointment of officers for positions unrelated to defense is a sign of the military interfering in politics.

As shown in the previous section, the three officers who were relevant voices in episodes of military contestation or who made public commentary about politics - Etchegoyen, Mourão, and Villas Bôas ${ }^{4}$ - were recruited for government positions after Rousseff's impeachment. In a sense, these active-duty top-rank generals became political before being called to serve in Temer and Bolsonaro's cabinets, which suggests a link between their previous activism and having been chosen by presidents to serve in their administrations. It also shows that, as far as the politician's dimension is concerned, part of the political class legitimizes the armed forces' role in politics as allies, indicating increasing relativization of an important democratic principle - that civilians must uphold the political neutrality of the military - a highly problematic trend for democracy. Analogously, society's view about the military's presence in government - public opinion and the view of relevant media outlets - should be considered. In the Brazilian example, a survey conducted in April 2019 showed that $60 \%$ of those interviewed approved of military officers occupying positions in the administration, while 36\% rejected it (Bächtold, 2020). Similarly, as I have argued elsewhere (Vitelli, 2020), the press has been ambivalent about military presence. It tends to overstate its assumed good qualities: moderation, pragmatism, competency, and nationalism.

Also, it is important to know whether members of the armed forces are being appointed in branches of power outside the executive. Our account shows that Brazilian officers served as Supreme Court judges' advisors. In that case, a more diverse presence of the armed forces should be assessed differently than mere appointments in cabinet, particularly considering the contemporary dynamics that characterize institutional crisis, in which soft coups and constitutional hardball tactics - in which Supreme Courts and Congresses play relevant roles in- are more widespread than traditional military coups.

\section{Episodes of military contestation:}

From 2011 to 2018 we identified three episodes of military contestation, all during Dilma Rousseff's government: the armed forces' disapproval of Amorim's selection as defense Minister; their criticism of the decree increasing the defense minister's powers regarding personnel issues; and the corporation's refusal to cooperate with the National Truth Commission's investigations.

The first element to consider regarding military contestation is the type of decision being contested, particularly, whether it is a government decision that affects the armed forces' core institutional interests or simply a policy unrelated to the corporation. Following Pion-Berlin's distinction between institutional and political autonomy (1992), it is reasonable to believe that even a strictly professional military is likely to challenge political authorities when they implement policies that could compromise the armed forces' professionalism and political neutrality. In these cases, contestation may only be the military's attempt to protect their apolitical character, devoid of any interest to influence policies that fall outside their turf, and, thus, posing no threat to democracy. On the contrary, officers can express their disapproval of democratic authorities' defense policy

\footnotetext{
${ }^{4}$ General Villas Bôas was appointed special counsel to the GSI in 2019.
} 
objectives and strategies, or even oppose policies unrelated to defense, in which case the contestation would resemble an act of tutelage, far more menacing for the stability and the quality of democracy. The Brazilian Army's refusal to cooperate with the National Truth Commission is an example of this.

Second, we should pay attention to the terms in which the military justifies its defiance. In the case of the criticism of Amorim's appointment, the armed forces dissatisfaction with their new chief was laid on ideological grounds, which is very likely a sign of the existence of an ideology or political opinion in the military, contrary to the democratic civilian control assumption of the armed forces' apolitical nature.

Third, the means through which the military articulates contestation also matters. Conflict articulated through institutional channels, mostly intermediated by the defense minister and respecting hierarchy, are less likely to have political impact when dealt with privately and through institutionalized procedures that guarantee civilian supremacy. In contrast, when officers speak directly to presidents, particularly in public, those are instances more similar to twentieth century military "pronunciamientos". Similarly, though less obvious, civil-military relations are also strained when officers choose to give off-the-record statements to the press in order to make their dissatisfaction public without visibly committing acts of indiscipline, as in the example of criticism of Amorim's appointment as defense minister and rejection of the decree that curtailed the military's influence over promotions.

As we pointed out earlier, politicians' reaction to military contestation is crucial to assessing risks for democracy. If authorities choose to maintain the course of the policy being questioned by the armed forces, but the consequence is further hostility from the military, conflict can escalate and jeopardize governability. It is also interesting to see whether opposition parties express solidarity with incumbent authorities - signaling that their commitment to democratic civilian control of the military goes beyond partisan interests. If, on the contrary, political opponents indicate agreement with the armed forces' questioning of official authorities rather than unity with their fellow civilians, it might be an indication of the polity entering a phase of civilian praetorianism. Society is less likely to react to episodes of military contestation, but any sign of civil society and the press condemning such events may be important deterrents against escalation, whereas expressions which favor the military's defiance may embolden more problematic forms of military intervention.

\section{Public commentary about political events}

It is normal for democracies to prohibit members of the military in active duty from making public political statements, so whenever an officer chooses to disobey the law, we should analyze their decision in terms of what made them evaluate that the costs of disobedience would outweigh the benefits. In that case, their decision signals a perception that the stakes are too high to remain silent, an assessment that may indicate they see further political activism as an option and, thus, not merely an exception. It may also be that civilians are so weak the military knows disciplinary sanctions will not be imposed. 
One of the elements we should consider is the content of statements. Any statement that is unrelated to the functioning of the military should be considered problematic: active-duty officers should not comment on political matters, regardless of the issue and the ideological view that informs those opinions. However, the content of the statements may point to further risks for democracy. The Brazilian example features the Chief of the Army and another member of the Army High Command talking at length about widespread corruption and an ethical crisis affecting society as a whole in the context of institutional distress. These ideas resonate with the discourse of antipolitics so common in the region's past authoritarian experiences in which the military portraited itself - with many civilians agreeing - as the saviors of the nation in times when politicians were seen as dishonest, incompetent, or coopted. A public opinion disenchanted with their political class may find those words very appealing and thus support or at least not oppose an autocratic backlash. Also, statements implying that elected authorities or their particular policies respond to foreign governments' interests, as well as claims of imminent security threats unaddressed by political leaders may have grave consequences too.

Similarly, the context in which officers' political speech takes place should be considered. While public commentary about political events is problematic as a rule, they may be even more dangerous when democratic institutions are undergoing some form of crisis. This is especially true when officers' messages remind society that the armed forces are the guardians of the nation, an elite unaffected by mundane problems such as corruption and partisanship. Both Generals Mourão and Villas Bôas' public commentary were problematic in terms of content and context.

When thinking about frequency and volume, determining how much political speech is too much might be impractical. Much less dubious is considering whether or not individual comments set out a chain reaction. Despite being an individual action, one officer speaking up may encourage other colleagues to follow suit, an indication of how popular the opinion is among soldiers and of how willing they are to engage in political activism once one of them breaks the ice. As said before, episodes of military contestation are collective, while public statements are subscribed by particular officers. This said, it is not always clear whether or not individuals are voicing opinions with the support of their colleagues, as seen in the case of General Villas Bôas' tweet, when other officers endorsed his words (Betim, 2018).

Finally, two considerations about rank should be made. First, given the importance that hierarchy has for the military as an institution, it is important to identify whether the officer who speaks up is on active duty and has command responsibilities. If so, despite being a personal comment, his or her voice is considered to represent the institution's standpoint. On the other hand, in two instances mentioned here a high-ranking officer justified his controversial actions as necessary means to avoid a reaction from officers and soldiers. Focusing on the tweets discussed, and according to later statements to the press, the Chief of the Army felt compelled to make such a controversial comment in order to guarantee discipline in the barracks. In this way, episodes that feature top-rank officers speaking about politics may reveal not only political activism among the top brass, but also a rank and file antagonistic to their civilian authorities. Best case scenario, democratically elected authorities have armed forces reticent to follow orders from their legitimate leaders. In the worst case, hostility and politization among soldiers and mid-rank officers can escalate into localized or even generalized insurrections. Restricted mutinies rarely topple 
governments, however, they open Pandora's Boxes, forcing civil and military authorities to further clash on the degree of severity with which to penalize rebels, which, in the context of wider political turmoil, can have unforeseeable consequences.

Regarding politicians, reactions to officers' public commentary is expressed in terms of whether they enforce disciplinary measures, fail to enforce punishment, or apply mild reprimands. Appeasement may be a sign of civilians' relative weakness to the armed forces, but it might also show something else. Civilian governments that witness officers speaking up about politics may not necessarily be interested in banning military involvement in politics. Dilma Rousseff's failure to impose herself on the armed forces shows a weakened administration, whereas Temer's inaction should be understood in the context of his reliance on the military as a backstage ally. As civilians acquiesce to a political role for the military, the deterioration of democracy deepens.

Similarly, society's reaction to officers' political speech offers relevant indicators of democracy's wellbeing. As far as the press is concerned, alarms should be raised when statements are requested by journalists. Some days after Villas Boas' comments about the institutional crisis, he gave an interview to an influential newspaper in which the Army Chief answered half a dozen questions about the political scenario (Monteiro, 2015b). In such cases, the country may not only have a politicized army, but also a militaristic society: one that sees the military as a social actor with its own outlook on the nation's problems, instead of merely armed public servants. In fact, the Army Chief's tweet episode revealed that these problematic societal views are widespread among Brazilians. Datafolha Institute asked Brazilians what they thought about the Army Commander making a statement with obvious political implications in a social network. Unsurprisingly, $61 \%$ agreed that the military could comment on the political situation, and only $33 \%$ saw it as inappropriate (Militares podem opinar sobre política, diz população 2018).

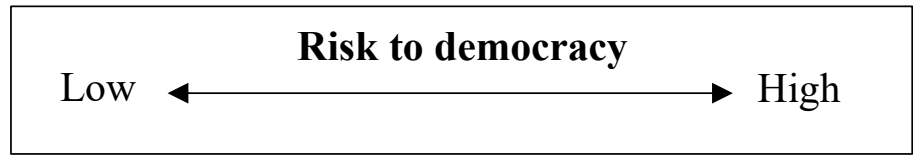

\begin{tabular}{|c|c|c|c|c|}
\hline \multirow{4}{*}{ 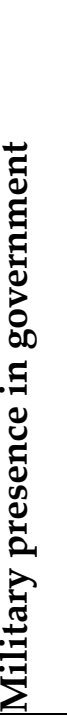 } & \multirow[b]{2}{*}{ 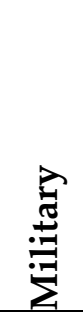 } & $\begin{array}{l}\text { Officers have previous history } \\
\text { of contestation / public } \\
\text { statements }\end{array}$ & No & Yes \\
\hline & & $\begin{array}{l}\text { Location of military } \\
\text { appointees }\end{array}$ & Executive power & Judiciary, Legislative \\
\hline & 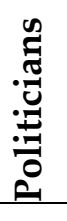 & Reason for appointment & Military coercion & $\begin{array}{l}\text { See the military as } \\
\text { political allies }\end{array}$ \\
\hline & 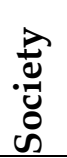 & $\begin{array}{l}\text { Assessment of public opinion } \\
\text { and the press }\end{array}$ & Disapprove & Approve \\
\hline
\end{tabular}




\begin{tabular}{|c|c|c|c|c|}
\hline \multirow{8}{*}{ 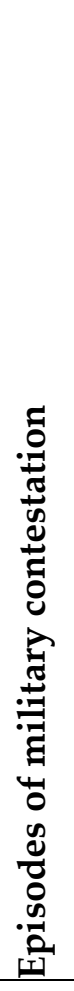 } & \multirow[b]{3}{*}{ 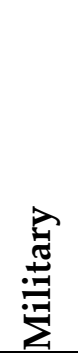 } & Type of issue & Institutional & Political \\
\hline & & Justification & Professionalism & Ideology \\
\hline & & Means & Institutional channels & $\begin{array}{l}\text { - Press (leaks, off-the- } \\
\text { record statements) } \\
\text { - Pronunciamientos }\end{array}$ \\
\hline & \multirow{4}{*}{ 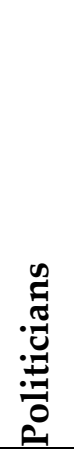 } & \multirow{2}{*}{ Policy } & \multirow{2}{*}{ Maintain, no instability } & Step back, no instability \\
\hline & & & & Maintain, instability \\
\hline & & Sanctions & $\begin{array}{l}\text { Disciplinary measures } \\
\text { do not cause turmoil }\end{array}$ & $\begin{array}{l}\text { Appeasement or further } \\
\text { contestation } \\
\text { sanctions }\end{array}$ \\
\hline & & Opposition & $\begin{array}{l}\text { Sides with the } \\
\text { Executive }\end{array}$ & Sides with the military \\
\hline & 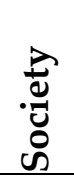 & $\begin{array}{l}\text { Reaction from civil society } \\
\text { organizations and the press }\end{array}$ & $\begin{array}{l}\text { Expresses concern over } \\
\text { civilian control of the } \\
\text { military }\end{array}$ & $\begin{array}{l}\text { No expressions of } \\
\text { concern }\end{array}$ \\
\hline \multirow{7}{*}{ 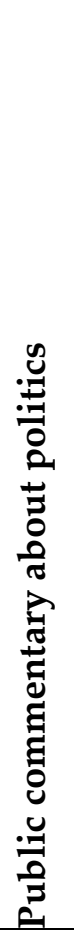 } & \multirow{5}{*}{ 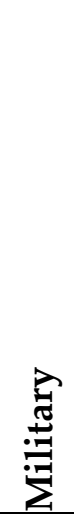 } & Content & $\begin{array}{lr}\text { Dissent, } & \text { though } \\
\text { respecting } & \text { democratic } \\
\text { institutions } & \end{array}$ & $\begin{array}{l}\text { Antipolitics discourse, } \\
\text { Infiltrated government, } \\
\text { Imminent threat }\end{array}$ \\
\hline & & Context & Non-crisis & Crisis \\
\hline & & Chain reaction & No & Yes \\
\hline & & Rank & Low & High \\
\hline & & Justification & & Appease the barracks \\
\hline & : & Sanctions & $\begin{array}{l}\text { Disciplinary measures } \\
\text { do not cause turmoil }\end{array}$ & $\begin{array}{l}\text { Accommodation and } \\
\text { appeasement }\end{array}$ \\
\hline & 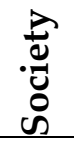 & Opinion & Disapproves & Approves \\
\hline
\end{tabular}

Figure A

\section{Concluding remarks}

B 
The prominent place in government that Brazilian military officers have enjoyed since 2019, as well as persistent public debates on the possibility of the armed forces deciding political stalemates compel scholars to return to classical questions of military involvement in politics as a threat to democracy, both by adjusting existing conceptual frameworks and paying closer attention to empirical instances of the phenomenon. By discussing such episodes since 2011, this article has aimed to show that signs of strained civil-military relations - particularly regarding democratization's first goal of eliminating military influence on politics - were visible long before Bolsonaro became a feasible presidential candidate. Secondly, by breaking up instances that indicate military involvement in politics and looking at them from the standpoint of the armed forces, politicians, and society, it becomes possible to conclude that it is a more widespread feature of Brazilian politics than commonly thought and, thus, a necessary element to assess the extent to which Brazil's democracy is under threat.

To sum up, every instance reflecting the three indicators ranks high on risks to democracy, including problematic attitudes across all three tiers: military presence in government featured officers who had become political while on active duty, before being called to serve in government. Their public comments on the course of domestic politics often signaled even more radical standings among the rank and file, and needed to be appeased to avoid insurrection. While military officers showed political activism, politicians often regarded them as allies, either being oblivious to or helpless before their political influence and articulated contestation. Society seldomly questioned the armed forces' politization.

While this paper's findings show that military involvement in politics predates Bolsonaro and will very likely outlive him - the field of civil-military relations should encourage further research on the factors that made it possible. One interesting question is in what ways the military used their autonomy on defense policy related spheres to retrieve their active role in politics, which could shed light on the links between institutional autonomy and political intervention in areas such as military education and doctrine, the institutional design of defense ministries, and defense budgets, among others. Moreover, scholars should revisit the link between internal missions and civilian control by looking into whether the military's involvement in crime fighting reinforced military political power. Finally, Brazil offers valuable insights for further comparative research on the current features of military involvement in politics, particularly in countries experiencing military unrest in connection with the rise of extreme right political movements. This includes Latin American countries such as Uruguay, Bolivia, and Peru, as well as well-established democracies like the United States, France, and Spain.

\section{References}

Bächtold, F. (2020, May 24). Pressão militar gestou artigo da Constituição usado em atos pró-golpe. Folha de S.Paulo.

Betim, F. (2018, April 4). Do general Villas Bôas à reserva, a ofensiva dos militares que querem voz na política. EL PAÍS. https://brasil.elpais.com/brasil/2018/04/02/politica/1522697550_276313.html 
Bruneau, T. C., \& Tollefson, S. D. (2014). Civil-Military Relations in Brazil: A Reassessment. Journal of Politics in Latin America, 6(2), 107-138.

Cantanhêde, E., \& Iglesias, S. (2009, December 30). Contra "Comissão da Verdade", comandantes ameaçam sair. Folha de S.Paulo. https://www1.folha.uol.com.br/fsp/brasil/fc3012200907.htm

Caram, B. (2017, August 28). Governo Temer é aprovado por 3\% e reprovado por 77\%, diz Ibope. G1. https://g1.globo.com/politica/noticia/governo-temer-e-aprovado-por-3-e-reprovado-por-77-dizibope.ghtml

Cavalcanti, L. (2020, July 17). 8.450 militares da reserva trabalham em ministérios, comandos e tribunais. Poder360. https://www.poder360.com.br/brasil/8-450-militares-da-reserva-trabalham-emministerios-comandos-e-tribunais/

Dreifuss, R., Oliveira, E. R. de, Quartim de Morais, J., \& Cavagnari Filho, G. L. (1987). As Foças Armadas no Brasil: Autonomia e tutela armada. Espaco e tempo.

Fitch, J. S. (1998). The Armed Forces and Democracy in Latin America. Johns Hopkins University Press.

Fuccille, A. (2006). Democracia e questão militar: A criação do Ministério da Defesa no Brasil [Doctorado]. IFCH-Unicamp.

GEDES. (2011a). Ministério da Defesa II: Celso Amorim é o novo ministro da Defesa e gera controvérsias (Informe Brasil No. 22/2011). https://gedes-unesp.org/observatorio-sul-americano-defesa-forcasarmadas/

GEDES. (2011b). Ministério da Defesa III: Nomeação de Amorim enfrenta resistência entre militares (Informe Brasil No. 23/2011). https://gedes-unesp.org/observatorio-sul-americano-defesa-forcasarmadas/

GEDES. (2015). Dilma Rousseff solicitou a anulação de decreto que transferiu poderes dos comandantes militares para o ministro da Defesa (Informe Brasil No. 32/2015). https://gedes-unesp.org/wpcontent/uploads/2018/06/Informe-Semanal-Brasil-Sul-Americano-32-2015.pdf

Gielow, I. (2018, November 11). “Bolsonaro não é volta dos militares, mas há o risco de politização de quartéis", diz Villas Bôas. Folha de S.Paulo. https://www1.folha.uol.com.br/poder/2018/11/bolsonaro-nao-e-volta-dos-militares-mas-ha-orisco-de-politizacao-de-quarteis-diz-villas-boas.shtml

Gielow, Igor. (2017, September 18). Ministro convoca o comandante do Exército para avaliar punição a general. Folha de S.Paulo. http://www1.folha.uol.com.br/poder/2017/09/1919553-ministroconvoca-o-comandante-do-exercito-para-avaliar-punicao-a-general.shtml

Godoy, Roberto. (2015, September 9) Tecnicamente correto, decreto é inoportuno. O Estado de São Paulo. https://politica.estadao.com.br/noticias/geral,tecnicamente-correto--decreto-e-inoportuno-imp-,1758744

Gregorio, R. (2017, September 20). Comandante do Exército descarta punir general que sugeriu intervenção. Folha de S.Paulo. http://www1.folha.uol.com.br/poder/2017/09/1920079-comandantedo-exercito-descarta-punir-general-que-sugeriu-intervencao.shtml 
Hunter, W. (1997). Eroding military influence in Brazil: Politicians against soldiers. University of North Carolina Press.

Marques, A. A. (2004). El Ministerio de Defensa en Brasil. Limitaciones y perspectivas. Revista Fuerzas Armadas y Sociedad, 18(3-4), 27-51.

Martínez, R. (2013). Objectives for democratic consolidation in the armed forces. In D. R. Mares \& R. Martinez (Eds.), Debating civil-military relations in Latin America (pp. 21-58). Sussex Academic Press.

Monteiro, T. (2014, March 14). Dilma orienta Defesa a não comemorar os 50 anos do golpe militar Política. Estadão. https://politica.estadao.com.br/noticias/geral,dilma-orienta-defesa-a-naocomemorar-os-50-anos-do-golpe-militar,1140999

Monteiro, T. (2015a, September 8). Dilma tira poderes de comandantes militares. Estadão. https://politica.estadao.com.br/noticias/geral,dilma-tira-poderes-de-comandantesmilitares, 1758021

Monteiro, T. (2015b, November 2). 'Há uma crise ética, mas instituições cumprem seu papel.' $O$ Estado de S. Paulo. https://politica.estadao.com.br/noticias/geral,ha-uma-crise-etica--masinstituicoes-cumprem-seu-papel,1789701

Monteiro, T., \& Tosta, W. (2014, December 10). Militares repudiam relatório da Comissão. O Estado de S. Paulo. https://politica.estadao.com.br/noticias/geral,militares-repudiam-relatorio-dacomissao, 1605184

Moraes, M. de. (2010, March 3). Jobim admite falha e garante que FAB não omitiu documentos secretos. O Estado de S. Paulo.

Pion-Berlin, D. (1992). Military Autonomy and Emerging Democracies in South America. Comparative Politics, 25(1), 83-102.

Pion-Berlin, D., \& Martínez, R. (2017). Soldiers, Politicians, and Civilians: Reforming Civil-Military Relations in Democratic Latin America. Cambridge University Press.

Saint-Pierre, H. L., \& Winand, E. (2010). A fragilidade da condução política da defesa no Brasil. História, 2, 3-29.

Saint-Pierre, H. L., \& Winand, É. C. A. (2008). A construção tardia do Ministério da Defesa como chave para compreender as particularidades do setor no Brasil. In I. Sepúlveda \& S. Alda (Eds.), La administración de La Defensa en América Latina: Vol. II (pp. 51-83). Instituto Universitario General Gutiérrez Mellado.

Stepan, A. (1988). Rethinking Military Politics. Brazil and the Southern Cone. Princeton University Press.

Stochero, T. (2015, October 20). General defende "despertar para luta patriótica" em palestra no RS. G1. http://g1.globo.com/politica/noticia/2015/10/general-defende-despertar-para-luta-patriotica-empalestra-no-rs.html

Valente, R. (2017, September 21). General que citou intervenção não será punido. Folha de S.Paulo. https://www1.folha.uol.com.br/poder/2017/09/1920079-comandante-do-exercito-descarta-punirgeneral-que-sugeriu-intervencao.shtml 
Vassallo, L. (2018, April 4). 'Não podemos repetir os erros do passado', alerta Lamachia. O Estado de S. Paulo. https://politica.estadao.com.br/blogs/fausto-macedo/nao-podemos-repetir-os-erros-dopassado-alerta-lamachia/

Vettorazzo, L. (2018, June 6). Alckmin escolhe general do Exército para equipe de segurança. Folha de S.Paulo. https://www1.folha.uol.com.br/poder/2018/06/alckmin-escolhe-general-do-exercitopara-equipe-de-seguranca.shtml

Vitelli, M (2020). Os militares no governo Bolsonaro (Informe Temático No. 1). Observatório SulAmericano de Defesa e Forças Armadas. https://gedes-unesp.org/wpcontent/uploads/2020/04/Informe-temático-Brasil-01-2019.pdf

Vizeu, R. (2015, October 14). Comandante do Exército vê risco de crise social no país. Folha de S.Paulo. http://www1.folha.uol.com.br/poder/2015/10/1693642-comandante-do-exercito-ve-risco-decrise-social-no-pais.shtml 